\title{
E-mail and mixed mode database surveys revisited: Exploratory analyses of factors affecting response rates
}

Received (in revised form) 17th June, 2004

\begin{abstract}
Abhijit Roy
is an assistant professor of marketing at the Sellinger School of Business, Loyola College in Maryland, USA. He has co-authored Taking Sides: Clashing Views on Controversial Issues in Marketing (McGraw-Hill/Dushkin) and published in a variety of marketing journals. His primary research interests are in marketing to and through associations and marketing and society issues.

\section{Paul D. Berger}

is a professor of marketing at the School of Management, Boston University, Massachussetts, USA. He earned his SB, SM, and $\mathrm{PhD}$ degrees from the Massachusetts Institute of Technology Sloan School of Management. In addition to being a co-author of Direct Marketing Management (Second Edition, 1999), he has also co-authored Cases in Business Statistics (1995), Experimental Design with Applications in Management, Engineering, and The Sciences (2002) and 101 Special Practice Problems in Probability and Statistics (2003). He is currently in the process of co-authoring a text with the tentative title The Theory and Practice of e-Enabled Marketing. He has published over 120 articles in academic journals such as Management Science, Journal of Marketing Research, Journal of Advertising Research, Journal of Direct Marketing, Journal of Interactive Marketing, Harvard Business Review, Sloan Management Review and The Journal of Database Marketing and Customer Strategy Management. He is on the editorial board of the Journal of Interactive Marketing and the International Quarterly Journal of Marketing. He won the Boston University Metcalf Award, a university-wide award for excellence in teaching.
\end{abstract}

\section{Abhijit Roy} Department of Marketing, Sellinger School of Business,

Loyola College in MD, 4501 N. Charles St., Baltimore, MD 21210, USA.

Tel: +1 410617 5837; Fax: +1 410617 2117; e-mail: aroy@loyola.edu
Abstract Two studies were conducted to test for factors affecting the overall response rates of e-mail and mixed-mode surveys. The surveys were directed at association executives who were asked to respond about the characteristics of their associations and their members.

The first study was international, involving association executives from six continents and 29 countries. It showed that the response rates were poor overall, with 'undeliverable' addresses as a potential problem. This global sampling frame was found to be unfeasible, given the very low response rates from association executives in most countries.

The subsequent study used a mixed mode approach and focused on executives within just the USA. The data collection process was specifically designed, in part, to enable certain comparisons among different e-mail survey options (eg degree of personalisation), as well as the core comparison of e-mail versus regular mail, with respect to response rates and other items of interest. Specifically, the authors found the response rate to be much higher for surveys mailed (versus e- mailed) to informants. Lottery incentives did not increase response rates for e-mail surveys. Only a small percentage (2.2 per cent) of informants who were mailed the 'paper' version of the questionnaire chose to fill it in online. On the other hand, none of the informants receiving the e-mail version of the questionnaire asked for the paper version.

There was no significant difference between the response rate for embedded versus attached e-mails; there was a marginally significant increase in response rate for personalised e-mails over that for non-personalised e-mail solicitations. Finally, the implications of these findings for using e-mail and mixed mode methodologies are addressed. 


\section{INTRODUCTION}

E-mail surveys are increasingly being used to collect data in industry - as noted by authors such as Shough and Yates $^{1}$ and Best and Krueger ${ }^{2}$ — as well as in acadaemia (see Schaefer and Dillman ${ }^{3}$ and Sheehan and $\mathrm{Hoy}^{4}$ as examples). Although this practice has been prevalent for over a decade and a half, researchers are continuing to explore ways of enhancing response rates and improving the efficiency of this mode of data collection (see Sheehan ${ }^{5}$ and Cook et al. ${ }^{6}$ for reviews).

In this paper, the authors first explore the usefulness of e-mail surveys in the context of a study involving association executives around the globe, involving six continents and 29 countries. After recognising some limitations with such an approach, they then use a mixed mode (eg e-mail and regular mail) study and investigate the relative successes and failures involved with such an effort. The authors begin by providing a brief description of their questionnaire, followed by a discussion of the first study. The main mixed mode study is then discussed - the email portion was specifically designed so that the impact on response rate of various factors, such as the degree of personalisation and whether the questionnaire was sent as an attachment or embedded, could be studied. Finally, the implications for considering e-mail and mixed mode surveys are also discussed and directions for future research are provided.

\section{THE QUESTIONNAIRE}

The survey instrument was developed on the basis of a literature search and review of the existing measures, as well as from suggestions made during field interviews. The measure development procedures recommended by Churchill ${ }^{7}$ and Gerbing and Anderson ${ }^{8}$ were carefully followed.
Multi-item scales were used to tap into most of the constructs used in the study. The (final) questionnaire can be seen in Appendix A. It may also be viewed online at http://people.bu.edu/ abhijitr/form.

As can be noted, there are seven pages of substantive questions. Section 1 asks for basic factual information about the association (eg how many members are in your association?'), and involves primarily 'fill-in-the-blank' requests. It includes a question geared towards categorising the association among the professional, common interest and hobbies, cause and commitment, and demographic sectors and asks the key informant to allocate 100 points among the four descriptions. Section 2 concerns the key informants' opinion of the members' degree of bonding and expressing affiliation with the association (eg 'most members in the association are committed to common goals'), and involves a series of answers on a Likert scale, 1 (strongly disagree) to 5 (strongly agree). Section 3 solicits the key informants' opinions on why members belong to the association (eg 'the opinion of the management of the association matter highly to the members'), and uses an importance scale of 1 (not at all) to 5 (extremely). Section 4 attempts to assess the general characteristics of the association; again, in the opinion of the key informant (eg 'our association is very selective about admitting new members'). The scale is the same scale as that used in section 2 . Section 5 continues soliciting the key informants' views of the thinking of the members (eg 'our members will seriously consider products and services recommended by the association'), and uses a 5-point scale from 1 (very unlikely) to 5 (very likely). Section 6 continues solicitation of opinions of the key informants, but now with respect to 
the views of the association leadership (eg 'the association has the expertise to make the right decisions') and, again, uses the same scale as that used in the previous section and in section 2 .

Section 7 asks the key informant to allocate 100 points among four descriptions of the association with respect to various different association attributes, for example, Leadership:

1 'the head of our association is considered to be a mentor, sage or parent figure';

2 'the head of our association is generally considered to be a coordinator, an organiser or an administrator';

3 'the head of our association is generally considered to be an entrepreneur, innovator or risk taker';

4 'the head of our association is usually considered to be a producer or a hard driver'.

Section 8, the last section, consists of fill-in-the-blank questions such as the gender of the key informant, how long he/she has been with the association, etc.

Association systems variables (centralisation, formalisation, exclusivity, localism, geographical coverage, hierarchy levels) were measured using multi-item scales contained in the questionnaire. In the same way, several other quantities of interest were operationalised. The details of these multi-item scales are not central to the main thrust of this paper.

\section{STUDY 1}

A pre-test of the questionnaire was conducted using e-mail. There were four distinct goals of this study: (1) to purify the measures and assess their reliability, (2) to obtain a preliminary sense of the hypotheses, (3) to assess overall response rate as well as response rates from various regions in the world, (4) to identify the remaining glitches and evaluate the overall feasibility of using an online questionnaire for the main study.

\section{Sampling frame}

The sampling frame for the pre-test was chosen from association executives listed in Associations Unlimited, the online version of Encyclopedia of Associations (Gale Publications, Farmington, MI) that had listed their e-mail addresses. International associations were also included in response to Gorn, ${ }^{9}$ Lehmann ${ }^{10}$ and others who have called for expanding the scope of enquiry to include marketing and customer research of global populations.

\section{Mode of administration}

As mentioned earlier, e-mail surveys were used to collect data for the first study. This mode was chosen primarily because of the potential efficiencies resulting from the complete elimination of paper, postage, mailing, and data entry costs (see Bachman et al. ${ }^{11}$ and Dillman ${ }^{12}$ as examples). In particular, it helped overcome the large expense of mailing the surveys to international destinations. In addition, the time required to implement the survey was reduced from weeks to a few days.

\section{Alternative options for conducting e-mail surveys}

There are many feasible ways to administer a questionnaire by e-mail. Prior to the advent of hypertext markup language (HTML), most researchers (eg Kiesler and Sproull; ${ }^{13}$ Schuldt and Totten; ${ }^{14}$ and Tse et al. ${ }^{15}$ ) used the simple text form, where the recipient is requested to hit the 'reply' command and scroll down the survey questions and 
answer them in the space provided. In some ways, one can consider these to be online versions of 'paper and pencil' surveys. Although this is by far the simplest method, it restricts the researcher's ability to send longer or more sophisticated questionnaires. One is restricted to using flat text, as graphics, colour and other aesthetic aids cannot be used in this form of questionnaire. There are no interactive controls as with traditional mail surveys. Respondents can change the wording of the questions to better reflect their responses. The researcher also has to be very careful in positioning the response spaces for fixed-alternative questions, since the responses may not remain aligned after transmission.

Other important ways of collecting data using e-mail include using downloadable software, outsourcing to an agent and using HTML forms. The pros and cons of the first two methods are not discussed here, as they were not used in this study. The final option, and perhaps the most efficient one (after a form has been created), is to create an HTML — based questionnaire and e-mail it to subjects using either an attached link or an embedded form. The former option involves providing the hypertext transfer protocol (http) link to the questionnaire, whereas the latter involves including the 'visible' form below the e-mail message. The 'attached link' may be a problem for respondents with e-mail accounts but without access to the World Wide Web. Moreover, many people are reluctant to 'click' on the link for fear of getting a virus from the downloaded files. Finally, some respondents with computers that are outdated or with limited capabilities may find it difficult to download the form. The 'embedded form' on the other hand, can seem overwhelming to some respondents when they open their e-mail. More importantly, the form may appear to look like 'garbled codes' to users of some specific types of e-mail program.

The authors used the 'attached link' format to collect the data. Although Dommeyer and Moriarty ${ }^{16}$ found the response rates from embedded surveys to be almost five times higher than attached surveys, the present authors chose the latter option because of e-mailing the form to countries where the recipient might not have had computer equipment sophisticated enough to open and read embedded forms. (It should be noted, though, that Dommeyer and Moriarty did not use HTML forms in their research. ${ }^{17}$ Instead they used the simple text-based e-mails as described above.) Also, during the pre-test of the two modes of delivery of the questionnaire, it was noticed that respondents not using 'Netscape-Mail' or 'Microsoft Outlook Express' for accessing their e-mails kept receiving 'garbled codes' reflecting the HTML codes used to construct the survey. Popular e-mail programs, such as 'Pine' and 'Eudora', do not have the capability of reading HTML coded scripts directly, thus creating problems for respondents using these programs.

\section{Key informants vs respondents as subjects}

As noted earlier, the study focussed on assessing the structural characteristics and other dynamics within associations, and their marketing implications. A contingency approach was taken to the study of these relationships - in other words, the question as to whether they are different for various major archetypes of association (professional, common interest, demographic and cause-based) was the key consideration. The focal unit of analysis in this case is the (type of) association.

Some have argued that using informants is necessary when raising the 
level from an individual to that of a group or an organisation, eg Kumar, Stern and Anderson. ${ }^{18}$ Respondents provide personal opinions about issues concerning themselves only. Typically, this method of data collection is used at an individual level of analysis (as noted by Mitchell). ${ }^{19}$ Respondents describe 'their personal feelings, opinions, and behaviors', whereas informants generalise 'about patterns of behaviour after summarising either actual (or observed) or expected (prescribed) organisational relations' $\left(\right.$ Seidler $^{20}$ ). Furthermore, Glick et al. ${ }^{21}$ suggest four specific advantages of collecting data from informants over respondents. These are as follows: (1) a higher probability of participation in the study (2) the most knowledgeable informant provides the data (3) low variation in informational and motivational biases across informants from a broad spectrum of organisations and (4) the potential of including a higher number of organisations within the constraints of a fixed budget.

Indeed, the simple fact is that, in this case, members of associations are not likely to be knowledgeable about many of the phenomena accounting for the constructs, such as hierarchical levels, centralisation, formalisation, heterogeneity, churn rate as well as size of the association. Thus, with the focal point of interest in the structural characteristics of associations, and the inter-organisational differences among them, executives and managers of associations are more likely to have knowledge and expertise about such phenomena. Hence, the 'key informant methodology' was used.

\section{Results}

Overall, the results indicated that:

1 The measures were tapping the constructs well, and so only minor revisions of the questions were warranted.

2 Certain hypotheses were supported while others were not.

3 The response rate was not encouraging

4 Hence the potential for using an e-mail questionnaire as the sole mode of administration was not promising.

5 A sampling frame consisting of associations from around the globe was found to be unfeasible, given the very low response rates from association executives from most countries outside the USA.

A high rate of undeliverable questionnaires compounded the problem of the low response rates for associations located in other countries.

\section{Response rate}

A random sample of 570 associations was selected from Encyclopedia of Associations. ${ }^{22}$ An approximately equal number of associations were selected from those headquartered within the USA (280) and those headquartered in other countries (290). The associations from within the USA were picked randomly, while a stratified sampling approach was used to select associations from other countries. Between 30 to 50 association executives from each continent were e-mailed the questionnaire.

The response rates across various countries are presented in Table 1. Of the 570 e-mails sent, 126 (22.10 per cent) could not be delivered to the recipient. A total of 51 responses were received, of which 48 were more than 50 per cent complete, and were thus considered usable for subsequent analysis. The response rate was calculated as: $100 \star 48 /(570-126)=10.81$ per cent. Using a more conservative base of 570 (the total number of e-mails sent), the 
Table 1: E-Mail response rates across various countries around the world

\begin{tabular}{|c|c|c|c|c|c|}
\hline Region & Country & $\begin{array}{l}\text { No of associations } \\
\text { with e-mail }\end{array}$ & $\begin{array}{l}\text { No } \\
\text { targeted }\end{array}$ & $\begin{array}{l}\text { No } \\
\text { undelivered }\end{array}$ & $\begin{array}{l}\text { No that } \\
\text { responded }\end{array}$ \\
\hline \multirow[t]{2}{*}{ North America } & USA & 39,619 & 280 & 46 & 29 \\
\hline & Canada & 1,524 & 40 & 11 & 5 \\
\hline \multirow[t]{3}{*}{ Central America } & Belize & 12 & 5 & 3 & 0 \\
\hline & Costa Rica & 32 & 10 & 4 & 0 \\
\hline & Mexico & 39 & 10 & 4 & 0 \\
\hline \multirow[t]{3}{*}{ South America } & Argentina & 50 & 10 & 5 & 0 \\
\hline & Brazil & 49 & 10 & 3 & 0 \\
\hline & Chile & 20 & 5 & 3 & 0 \\
\hline \multirow[t]{5}{*}{ Africa } & Ethiopia & 15 & 10 & 3 & 0 \\
\hline & Kenya & 64 & 10 & 2 & 0 \\
\hline & Nigeria & 24 & 10 & 2 & 0 \\
\hline & S. Africa & 139 & 10 & 1 & 1 \\
\hline & Zimbabwe & 97 & 10 & 4 & 1 \\
\hline \multirow[t]{2}{*}{ Australasia } & Australia & 281 & 25 & 6 & 3 \\
\hline & New Zealand & 149 & 25 & 9 & 6 \\
\hline \multirow[t]{6}{*}{ Asia } & Azerbaijan & 9 & 5 & 3 & 0 \\
\hline & India & 130 & 10 & 1 & 1 \\
\hline & Japan & 165 & 10 & 2 & 0 \\
\hline & Malaysia & 64 & 10 & 3 & 0 \\
\hline & Philippines & 57 & 5 & 1 & 0 \\
\hline & Singapore & 40 & 10 & 0 & 1 \\
\hline \multirow[t]{8}{*}{ Europe } & Belgium & 519 & 5 & 0 & 0 \\
\hline & England & 2,681 & 10 & 2 & 1 \\
\hline & France & 369 & 5 & 1 & 0 \\
\hline & Germany & 408 & 10 & 3 & 1 \\
\hline & Italy & 147 & 5 & 2 & 0 \\
\hline & Netherlands & 306 & 5 & 1 & 1 \\
\hline & Spain & 67 & 5 & 1 & 0 \\
\hline & Sweden & 172 & 5 & 0 & 1 \\
\hline
\end{tabular}

response rate is found to be: $100 \star 48 / 570=8.42$ per cent.

As far as specific countries are concerned, the best response was from New Zealand (24 per cent, six responses from 25 solicitations), followed by Canada (12.5 per cent, 5/40), Australia (12 per cent, $3 / 25)$, and the USA (10.36 per cent, 29/280). No responses were received from 17 of the 29 countries targeted in the pre-test, and there was only one response each from nine other countries. The higher response rates were from association executives from the English speaking industrial countries. Unfamiliarity with the English language and the survey methodology, and the unavailability of appropriate computer technology, may have contributed to the low response rates from many countries targeted in this survey. Different operating platforms (eg PC versus
Macintosh); different browsers (eg Netscape versus Internet Explorer); and even different versions of the same browser may have resulted in questionnaire items being displayed differently on the respondent's computer as compared with the designer's computer. Respondent frustration with browser limitations, the length of the questionnaire and the unconventional questionnaire format may also have contributed to the lower response rate.

The high percentage of undelivered surveys is a major concern. As stated earlier, more than one in five electronic surveys did not reach the recipient's mailbox. The 'undelivered rate' was 16.43 per cent (or $100 \star 46 / 280$ ) for e-mail surveys sent within the USA, versus 27.59 per cent, (or $100 \star 80 / 290$ ) for e-mail surveys sent outside the USA. Although electronic surveys provide 
potential for overcoming international boundaries as significant barriers to conducting surveys, researchers using this particular sampling frame (ie Encyclopedia of Associations database ${ }^{22}$ ) should be aware of the problem of undeliverable surveys.

\section{STUDY II}

The main research study involved a mixed mode survey as described by Dillman. ${ }^{24}$ This was partly motivated by research showing that multiple modes of survey delivery yielded higher response rates as noted by Yun and Trumbo, ${ }^{25}$ as well as the authors' desire to compare the relative effectiveness of the two modes of administration. Although earlier studies had compared e-mail and mail response rates in a variety of contexts (see Couper et al. ${ }^{26}$ Kittleson; ${ }^{27}$ McDonald and Adam; ${ }^{28}$ and Paolo et al., ${ }^{29}$ as some examples), the authors also investigated whether informants would switch modes of filling out the survey, if given that option.

During the first phase, the informants initially were mailed a paper survey. They were, however, also given the link to the questionnaire on the web and so had the option of filling out the form online. Later, during the second phase, 100 (different) randomly-selected informants were e-mailed two different types of HTML form, attached and embedded. These informants were given the option of filling out a paper version of the questionnaire. The sample selection process, the general characteristics of the instrument, the data collection procedure and the response rates are discussed below.

\section{Sample selection}

The sample was again selected from Encyclopedia of Associations database. ${ }^{30}$ The questionnaire was developed (based upon the results of the pretest) and mailed to the executives listed for each selected association. The sample was selected from ten eastern states (Connecticut, Maine, Maryland, Massachusetts, New Hampshire, New York, Pennsylvania, Rhode Island, Virginia and Vermont) and two mid-western states (Illinois and Wisconsin).

Most of the data was collected from the eastern states for three major reasons. First, a north-eastern (New England states) version and a mid-Atlantic version of this database was conveniently available and appeared more manageable, given that the goal was to mail the questionnaires to only about 1,000 associations. Secondly, an assumption was made that informants located in states in close proximity to the authors' university (both authors were from the same university at that point in time) were more likely to demonstrate 'camaraderie' in helping out folks from their region. Finally, given the time constraints faced in completing this project, it was more likely that the questionnaires would be returned sooner than if they had been mailed to more distant destinations. To check for any non-sampling biases, however, the authors also selected for their sampling frame associations from the two mid-western states.

The authors made sure that all associations targeted were individual membership-based entities. In other words, business- or commercial-based associations, such as chambers of commerce, tourism departments, conference and visitors' bureau, regional business alliances, and retail marketing services, were eliminated from the sampling frame. From among individual-membership-based associations, the authors also ensured that marketer-generated associations such as frequent flier clubs, were not included in this study. All associations selected 
appeared to meet the criteria of being either a professional, common interest, cause-based or demographic association. Only associations providing the name of an executive were included - so that cover letters could be personalised. Doing so has been shown to improve response rates as shown by Dillman. ${ }^{31}$ Neither the size of an association, nor its annual budget, was a consideration in the selection process.

\section{Instrument characteristics}

In designing the survey instrument, care was taken to convey a high level of professionalism. The questionnaire was designed as an eight page ( 8.4 inch by 11 inch) double-sided booklet, which was saddle stapled. The cover of the booklet included: (1) the title — ' $A$ Survey of Association Characteristics and Membership Behavior; (2) a university logo; and 3) the university address, e-mail and phone number of one of the authors.

The online version of the questionnaire was created using Frontpage 3.0 (Microsoft), and Dreamweaver (Macromedia). It was loaded on the university server using Pony Express, a customised CGI (scripting language) that reads data into a database when it is received. As recommended by Dillman, ${ }^{32}$ limited colour contrasts were used so that figure/ground consistency and readability, navigational flow and measurement properties were maintained.

Although every effort was made to keep the two modes of questionnaire as similar as possible, in the interest of achieving equivalent form reliability, there were a couple of minor differences worth noting. First, 'check boxes', 'drop down lists', 'radio buttons', 'text boxes' and 'command buttons' (submit form and clear form) were used in the electronic version of the questionnaire. These enhancements were leveraged to make it easier for the informant to respond to the questions. For example, Question 4c in the paper survey asked:

'Approximately what percentage of your members visit your web site?' and allowed the informant to write in an answer. The same question on the web offers a 'drop down' list of options in increments of 10 per cent, ie 10 per cent, 20 per cent, 30 per cent, etc. The advantage here is that the informant can click on the most appropriate answer instead of writing in his or her response, thus saving some time. Second, as mentioned earlier, a minimal amount of colour and graphics were used, and the order of the questions was slightly altered in the electronic version, to make it aesthetically pleasing in appearance.

The questionnaire was restricted to using 5-point scales (as was described earlier) because the electronic version would not accommodate higher point scales. The column width for computer screens varies greatly, and, in smaller monitors, texts had a tendency to wrap-around when the line length was greater than 70 characters. It was pre-tested several times to eliminate all the remaining problems with its administration.

\section{Data collection process}

Data were collected over a four-week period. A total of 1,006 questionnaires were mailed during this period. Each mailing included: (1) a personalised cover letter (on university letterhead with hand-written signature) that explained the significance of the research and the importance of participation; (2) the survey booklet and (3) a prepaid stamped return envelope with the researcher's name and address at the university. In the cover letter, the authors emphasised that the data were to be used strictly for 
research, and respondents were promised complete confidentiality. A personalised hand-written note stating: 'Your help is much appreciated!' was written on every letter mailed.

As a token of appreciation, an 'Executive Summary' of the results was offered, and responders were entered into a draw for one of three $\$ 100$ gift certificates. Respondents were also provided with a URL for the questionnaire and had the option of filling out the questionnaire on-line.

The second phase involved transmitting the questionnaire via e-mail to randomly selected association executives within the USA a month or so later. As noted earlier, this random selection excluded the aforementioned 1,006 questionnaires mailed in the first phase. A total of 112 e-mail solicitations were attempted; 12 were undeliverable, thus 100 e-mails were successfully delivered. Half of these questionnaires (50) were embedded within the e-mail, the other half of the sample was provided with the link to the questionnaire on the web. Half of the informants in both conditions were sent a personalised letter, while the other half in both conditions was not specifically addressed by name (the salutation read, 'Dear Sir or Madam'). Thus, there were four 'cells' of 25 questionnaires each, representing the four combinations of 'embedded or not' and 'personalisation or not'. Informants were given the option of filling out the questionnaire online or requesting a mail survey.

\section{Response rates}

The response rate obtained for the study was 42.2 per cent, calculated as follows: of the potential 1,006 respondents, 65 were considered ineligible as they were returned marked 'return to sender', 'no longer with company', or the association felt that it did not meet the criteria for the study. Of the remaining 941 potential respondents, 381 responded by mail and 22 responded via e-mail. Therefore, the response rate was calculated as $100 \star(381+22) / 941=42.83$ per cent.

Using the more conservative 1,006 potential respondents in the sampling frame as a base, the response rate is 40.05 per cent. During the second phase of the study, 11 executives (out of the 100) filled out the questionnaire online resulting in a response rate of 11 per cent, no one requested a copy of the mail survey. The overall response rate, therefore, was $100 \star(381+22+11)$ / $(941+100)=39.77$ per cent.

The moderately high response rate from the mail survey may be attributable to: (1) perceived importance of the topic; (2) perceived professionalism of the survey; (3) a personalised cover letter including a hand written 'your help is much appreciated' note; and (4) financial incentive in the form of a lottery draw.

Carlson ${ }^{33}$ compared three forms of incentive: no incentive, a chance to win $\$ 300$ and a two-dollar bill, and found a response rate of 54 per cent for the no incentive control group compared with 58 per cent for the lottery and 73 per cent when the two-dollar bill was sent. Hence, the lottery may not have contributed to the response rate to a significant degree. Nevertheless, it was used in light of the poor response rate obtained during the pre-test. Pre-paid financial incentives were not employed due to budgetary constraints.

The response rate for the e-mail version of the survey continued to be a problem. The numbers are particularly low compared with those of some other studies. In many cases, (eg Mehta and Sivadas; ${ }^{34}$ Opperman; ${ }^{35}$ and Schaefer and Dillman) $)^{36}$ e-mail response rates reported were better than those for the mail version. 
Based on qualitative feedback received from non-respondents as well as from respondents who had encountered initial problems in responding to our online survey, the authors propose that several factors have to be taken into account.

First, the length of the questionnaire may have been a major deterrent to the informants. The authors' questionnaire had 112 questions compared with 55 questions asked by Dommeyer and Moriarty ${ }^{35}$ and 46 by Schaefer and Dillman, ${ }^{38}$ Sheehan's meta analysis of all e-mail studies conducted to date showed that the average number of questions used in an e-mail study was 42.3. Interestingly, there was no significant correlation between response rate and the number of questions in the survey, although it is worth noting that the maximum number of questions used in e-mail surveys to date was $94(n=31)$. Furthermore, recent research (eg Deutskens et al. ${ }^{39}$ ) has also demonstrated in an experimental context that shorter questionnaires have a significantly higher response rate than longer questionnaires.

Secondly, the HTML version of the questionnaire (rarely used in earlier studies) may have created a problem for many respondents. There was no way of knowing if the text had become misaligned, if questions were not fully visible on the respondent's screen or if there was a change in visual appearance of questions because features installed by the authors were disabled by the respondent's computer.

Thirdly, the authors did not use follow-up questionnaires, unlike most other studies, because of their interest in comparing the responses across the two modes of survey without any prompting, as well as because of budgetary constraints. Fourth, in many cases, the e-mail address provided by the association may not have been that of the intended executive - thus, he or she may not have received the questionnaire. Fifth, the informant's identity is typically revealed in e-mail surveys, and so the perception of the lack of anonymity could deter some from participating. The authors did, however, programme Pony Express to maintain the privacy of the informant, and not to disclose their e-mail address unless it was voluntarily provided.

Finally, with the exponential increase in e-mail marketing in just the last few years, many people are deluged with so many solicitations that they do not respond to requests. Sometimes, even with good intentions, an informant forgets to respond to an e-mail. It is also much easier to delete or ignore e-mail messages than regular mail.

The response rate during the second phase of the study may be further broken down as shown in Table 2 . The authors first tested whether the response rate to embedded surveys was equal to that of attached surveys; no significant difference was found ( $p=0.750$, two-tailed test), unlike the findings of Dommeyer and Morriarty. ${ }^{41}$ They then tested whether personalised mailings yield a significantly higher response rate than those that are not personalised and found a marginally significant difference ( $p=0.056$, one-tailed test). Past research $\left(\right.$ eg Dillman ${ }^{42}$ ) has shown that personalisation often increases response rates. The authors also tested whether or not there was interaction between the personalisation treatment and e-mail mode treatment and found no

Table 2: E-mail survey response rates for different treatments

\begin{tabular}{lll}
\hline \multirow{2}{*}{$\begin{array}{l}\text { Use of } \\
\text { personalisation }\end{array}$} & \multicolumn{2}{c}{ Type of e-mail } \\
& Embedded & Attached \\
\hline Personalised & 5 (out of 25) & 3 (out of 25) \\
Not personalised & 1 (out of 25) & 2 (out of 25) \\
\hline
\end{tabular}


significance ( $p=0.424$, two-sided test). They realise that any test of proportions with such low sample sizes has extremely low power, as well as needing a relatively large difference in sample proportions to reject the null hypothesis of equality. Nevertheless, with these understandings, there is no reason not to perform the hypothesis tests.

\section{ASSESSMENT OF NON-RESPONSE BIAS}

An assessment of non-response bias (as proposed by Armstrong and Overton ${ }^{43}$ ) showed no significant differences between early (first 75 per cent) and the late (last 25 per cent) respondents on the number of members in the association and the age of the association. However, the associations answering by paper survey were slightly larger in membership size than their e-mail counterparts $(p=0.020)$ and more established (ie older), ( $p=0.078)$.

\section{CONCLUSIONS AND IMPLICATIONS}

The use of e-mail surveys has gained in popularity in just the last 15 years and continues to offer an exciting opportunity for researchers primarily because of low costs and quick response times. Even though over 30 academic studies (see Cook et al. ${ }^{44}$ and Sheehan ${ }^{45}$ for the references) have reported on the several factors affecting response rates, the present research hopefully sheds some new light on the efficiency and effectiveness of e-mail and mixed mode surveys.

This research broke new ground in the sense that the authors are able to report e-mail response rates from 29 countries across all continents in the world. It is also the first study to date to evaluate the potential pros and cons of HTML based 'embedded' and 'attached' e-mail surveys. The number of questions $(n=106)$ used in an online survey was the largest so far to be reported in the literature. Specifically, the authors found the response rate to be much higher for surveys mailed to informants than it was for surveys e-mailed to informants. Lottery incentives did not increase response rates for e-mail surveys. Only a small percentage (2.2 per cent) of informants who were mailed the 'paper' version of the questionnaire chose to fill it out online. On the other hand, none of the 100 informants receiving the e-mail version of the questionnaire asked for the paper version.

There was no significant difference between the response rates for embedded versus attached e-mails; there was a marginally significant increase in response rate for personalised e-mails over that for non-personalised e-mail solicitations. Thus, although it may appear to be tempting to use batch e-mails (mailing to multiple e-mail addresses simultaneously) as well as listservs or electronic newsgroups to save time, informants may appreciate being addressed individually, feeling that they are important and not just an item on a list.

It is estimated that over 2.3 billion spam messages travel through cyberspace everyday, people are increasingly deleting e-mails that are sent anonymously. Ironically, even the Direct Marketing Association (DMA) is lobbying hard to change US state and federal laws that would aim to control unsolicited e-mail activities as noted by Krane. ${ }^{46}$ Thus, pre-notification (see Taylor and Lynn; ${ }^{47}$ Fox et al.; ${ }^{48}$ Haggett and Mitchell ${ }^{49}$ as examples), permission (Kent and $\mathrm{Brandal}^{50}$ ) and salience (Sheehan and McMillan ${ }^{51}$ ) should also be considered in addition to personalising the message.

Finally, response rates for e-mail solicitations from associations located 
(outside the USA) were found to be much lower than those from within the USA. Although Sheehan ${ }^{52}$ identifies the increase in surveying within the USA as a major reason for diminishing response rates, it appears that unfamiliarity and lack of technological infrastructure may be a greater deterrent in attempting to collect data from other countries. As the world becomes much smaller with the advent of the 21st century, such differences are likely to diminish in the near future.

There was a wide variance in these response rates, with the response rate from developed English-speaking countries being much higher than the response rate from other countries. There were some slight indications of response bias, but nothing that materially affects the conclusions of the main study. As noted, the sample sizes used for some of the hypothesis tests were quite small for testing differences in proportions; hence, they may be better treated as a "case study', to put the analyses into the proper perspective.

There is unequivocal evidence, as shown in this study and in previous studies (eg Schafer and Dillman; ${ }^{53} \mathrm{Tse}^{54}$ ), that the reliability and validity of data collected through e-mail surveys are as strong as those collected through any other modes, and, moreover, this approach offers the additional advantages of low cost, quick turnaround and higher efficiencies. As Dillman ${ }^{55}$ notes, 'no other method of collecting survey data... offers so much potential for so little cost'. However, in a rapidly changing technological environment, even as e-mail response rates continue to plummet, researchers should continue to explore how this mode of survey administration can be improved as a stand-alone technique or how it can best be integrated with traditional survey approaches.

\section{References}

1 Shough, S. and Yates, D. (2002) 'The Advantages of an e-mail survey', Journal of Applied Business Research, Vol. 18, No. 2, pp. 37-45.

2 Best, S. J. and Krueger, B. (2002) 'New approaches to assessing opinion: The prospects for electronic mail surveys', International Journal of Public Opinion Research, (Spring), Vol. 14, No. 1, pp. 73-92.

3 Schaefer, D. R. and Dillman, D. A. (1998) 'Development of a standard e-mail methodology: Results of an experiment', Public Opinion Quarterly, Vol. 62, No. 3, pp. 378-390.

4 Sheehan, K. and Hoy, M. G. (1999) 'Using e-mail to survey internet users in the United States: Methodology and assessment', Journal of Computer Mediated Communication, Vol. 4, No. 3, Available at http://www.ascusc.org/jcmc/vol4/ issue 3/sheehan.html.

5 Sheehan, K. (2001) 'E-mail survey response rates', Journal of Computer Mediated Communication, Vol. 6, No. 2, January, pp. 1-20.

6 Cook, C., Heath, F. and Thompson, R. (2000) 'A Meta-analysis of Response Rates in Webor Internet-based surveys', Educational \& Psychological Measurement, Vol. 60, No. 6, pp. 821-836.

7 Churchill, G. A. Jr. (1979) 'A paradigm for developing better measures of marketing constructs', Journal of Marketing Research, Vol. 16, (February), pp. 64-79.

8 Gerbing, D. W. and Anderson, J. C. (1988) 'An updated paradigm for scale development incorporating unidimensionality and its assessments', Journal of Marketing Research, Vol. 25 (May), pp. 186-192.

9 Gorn, G. J. (1997) 'Breaking out of the North American box', in M. Brucks and D. J. MacInnis (eds), Advances in Consumer Research, Vol. XXIV, pp. 6-9.

10 Lehmann, D. (1999) 'Consumer behavior and Y2K', Journal of Marketing, Vol. 63, (Special Issue), pp. 14-18.

11 Bachmann, D., Elfrink, J. and Vazzana, G. (1999) 'E-mail and snail mail face off in rematch', Marketing Research, Vol. 11, No. 4, pp. 11-15.

12 Dillman, D. A. (2000), 'Mail and internet surveys: the tailored design method', John Wiley and Sons, New York, NY.

13 Kiesler, S. and Sproull, L. S. (1986) 'Response effects in the electronic survey', Public Opinion Quarterly, Vol. 50, pp. 402-413.

14 Schuldt, B.A. and Totten, J. W. (1994) 'Electronic mail vs. mail survey response rates', Marketing Research, Vol. 6, (Winter), pp. 36-39.

15 Tse, A., Tse, K. C., Yin, C. H., et al. (1995) 'Comparing the two methods of sending out questionnaires: E-mail versus mail', Journal of Market Research Society, Vol. 37, No. 4, pp. 441-445.

16 Dommeyer, C. J. and Moriarty, E. (2000) 'Comparing two forms of an e-mail survey: 
Embedded vs. attached', International Journal of Market Research, Vol. 42, No. 1, pp. 39-49.

17 Ibid.

18 Kumar, N., Stern, L. W. and Anderson, J. C. (1993) 'Conducting interorganizational research using key informants', Academy of Management Journal, Vol. 36, No. 6, pp. 1633-1653.

19 Mitchell, V. W. (1994) 'Using industrial key informants: Some guidelines', Journal of Market Research Society, Vol. 36, pp. 139-145.

20 Seidler, J. (1974) 'On using informants: A technique for collecting quantitative data and controlling for measurement error in organizational analysis', American Sociological Review, Vol. 39, p. 817.

21 Glick, W. H., Huber, G. P., Miller, C. C. et al. (1990) 'Studying changes in organizational design and effectiveness: Retrospective event histories and periodic assessments', Organizational Science, Vol. 1, pp. 293-312.

22 Encyclopedia of Associations, (2000) Gale Publications: Farmington Hills, MI.

23 Encylopedia of Associations (2000) op cit.

24 Dillman (2000) op. cit.

25 Yun, G. W. and Trumbo, C. W. (2000) 'Comparative response to a survey executed by post, e-mail and web form', Journal of Computer Mediated Communication, Vol. 6, No. 1, Available at http://www.ascusc.org/jcmc/vol6/issue1/ yun.html.

26 Couper, M. P., Blair J. and Triplett, T. (1997) 'A comparison of mail and e-mail for a survey of employees in federal statistical agencies', Paper presented at the Annual Meeting of American Association for Public Opinion Research, Norfolk, VA.

27 Kittleson, M. J. (1995) 'An assessment of the response rate via the postal service and e-mail', Health Values, Vol. 18, No. 2, pp. 27-29.

28 McDonald, H. and Adam, S. (2003) 'Comparison of online and postal data collection methods in marketing research', Marketing Intelligence and Planning, Vol. 21, No. 2, pp. 85-95.

29 Paolo, A. M., Bonaminio, G. A., Gibson, C. et al. (2000) 'Response rate comparisons of e-mail and mail distributed student evaluations', Teaching and Learning in Medicine, Vol. 12, No. 2, pp. 81-84.

30 Encyclopedia of Associations (2000) op. cit.

31 Dillman, D. A. (1991) 'The design and administration of e-mail surveys', Annual Review of Sociology, Vol. 17, 225-249.

32 Dillman (2000) op. cit.

33 Carlson, J. (1996) 'Results of personalization experiments', paper presented at the Changes in Organizational Design and Effectiveness: Retrospective Event Meeting of W-183, Regional Research
Committee, Tucson, AZ.

34 Mehta, R. and Sivadas, E. (1995) 'Comparing response rates and response content in mail versus electronic surveys', Journal of the Market Research Society, Vol. 37, No. 4, pp. 429-440.

35 Oppermann, M. (1995) 'E-mail surveys Potentials and pitfalls', Marketing Research, Vol. 7 , No. 3, pp. 28-34.

36 Schaefer and Dillman (1998) op. cit.

37 Dommeyer and Moriarty (2000) op. cit.

38 Schaefer and Dillman (1998) op. cit.

39 Sheehan (2001) op cit.

40 Deutskens, E., Ruyter, K. D., Wetzels, M. and Oosterveld, P. (2004) 'Response rate and response quality of internet based surveys: An experimental study', Marketing Letters, Vol. 15, No. 1, pp. 21-36.

41 Dommeyer and Moriarty (2000) op. cit.

42 Dillman (1991) op. cit.

43 Armstrong, S. and Overton, T. S. (1977)

'Estimating non-response bias in mail surveys', Journal of Marketing Research, Vol. 14, (August), pp. 396-402.

44 Cook, Heath \& Thompson (2000) op. cit.

45 Sheehan (2001) op. cit.

46 Krane, J. (2002) 'DMA lobbies for law to control unsolicited e-mail', Marketing News, Vol. 36, No. 23, pp. 21-23.

47 Taylor, S. and Lynn, P. (1998) 'The effect of a preliminary notification letter on response to a postal survey of young people', Journal of the Market Research Society, Vol. 40, No. 2, pp. 165178.

48 Fox, R, Crask, M. R. and Kim, J. (1988) 'Mail survey response rates: A meta-analysis of selected techniques for inducing response', Public Opinion Quarterly, Vol. 52, pp. 467-491.

49 Haggett, S. and Mitchell, V. (1994) 'Effects of industrial pre-notification on response rate, speed, quality, bias and cost', Industrial Marketing Management, Vol. 23, pp. 101-110.

50 Kent, R. and Brandal, H. (2003) 'Improving e-mail response in a permission marketing context', International Journal of Market Research, Vol. 45, pp. 489-496.

51 Sheehan, K. and McMillan, S. J. (1999) 'Response variation in e-mail surveys: An exploration', Journal of Advertising Research, Vol. 39, No. 4, pp. 45-54.

52 Sheehan (2001) op. cit.

54 Schaefer and Dillman (1998) op. cit.

55 Tse, A. (1998) 'Comparing the response rate, response speed and response quality of two methods of sending questionnaires: E-mail vs. mail', Journal of the Market Research Society, Vol. 40, No. 4, pp. 353-361.

56 Dillman (2000) op. cit. p. 400. 


\section{APPENDIX A: A SURVEY OF ASSOCIATION CHARACTERISTICS \& MEMBERSHIP BEHAVIOUR}

\section{Section I:}

At the outset, please provide the following information about your association:

1. In what year was the association formed?

2. How many members are there in your association:

3a. Is this $\mathrm{a}(\mathrm{n})$ : international national regional state local association?

b. How many levels of management are there in your association? levels

4a. Does your association have a web site? Yes No [If 'No', please skip to Q.5]

b. For how long has your association had a web site? years

c. Approximately, what percentage of your members visits your web site? per cent.

5. Which of the following services does your association offer (please check all that apply):

A. Insurance:

Life insurance Health insurance Property/Casualty Other

$$
\text { (please specify) }
$$

\section{B. Financial Services:}

Mutual funds Pension plans Credit cards Home mortgages Other (please specify)

\section{Membership Discounts:}

Car rental services Long distance telephone Travel services Other

$$
\text { (please specify) }
$$

6. These questions relate to what your association is like. Given below are four descriptions of associations. Please distribute 100 points among the four descriptions depending on how well they apply to your organization. None of the descriptions are any better than any other; they are just different. Please use all 100 points.

points Our association recognizes professional status and provides career advancement opportunities for members.

points Our members share common interests and hobbies.

points Our association demonstrates both cause and commitment to advancing our mission. 
points Our members are linked according to demographic characteristics such age, education, ethnicity or region.

100 points Total

7. How would you best characterise your association:

Athletic and sports

Chambers of Commerce, Trade and

Tourism

Cultural organisations

Educational organisations

Engineering, technological,

natural sciences

Environmental and agricultural

organisations

Fan clubs

Fraternal, nationality and ethnic

organisations

Greek and non-Greek letter societies

and federations
Health and medical organisation Hobby and avocational Labour unions and federations Legal, governmental and military

Public affairs

Religious

Social welfare

Travel, business and commercial

Other, please specify

\section{Section II:}

This section concerns the degree of bonding and expressing affiliation with the association. How strongly do you agree or disagree with the following statements:

\begin{tabular}{|c|c|c|c|c|c|}
\hline & $\begin{array}{l}\text { Strongly } \\
\text { disagree }\end{array}$ & Disagree & Neutral & Agree & $\begin{array}{l}\text { Strongly } \\
\text { agree }\end{array}$ \\
\hline $\begin{array}{l}\text { 1. Most members in the association are } \\
\text { committed to common goals. }\end{array}$ & 1 & 2 & 3 & 4 & 5 \\
\hline $\begin{array}{l}\text { 2. There is a sense of cooperation amongst } \\
\text { members. }\end{array}$ & 1 & 2 & 3 & 4 & 5 \\
\hline $\begin{array}{l}\text { 3. Most members do not care enough about } \\
\text { the association. }\end{array}$ & 1 & 2 & 3 & 4 & 5 \\
\hline $\begin{array}{l}\text { 4. There are several joint activities that } \\
\text { members are involved in. }\end{array}$ & 1 & 2 & 3 & 4 & 5 \\
\hline $\begin{array}{l}\text { 5. There are many volunteers that work } \\
\text { very hard for the association. }\end{array}$ & 1 & 2 & 3 & 4 & 5 \\
\hline $\begin{array}{l}\text { 6. The members take every chance to } \\
\text { disclose their membership in this group } \\
\text { to society at large. }\end{array}$ & 1 & 2 & 3 & 4 & 5 \\
\hline $\begin{array}{l}\text { 7. Our meetings and/or libraries are not open } \\
\text { to the public at large. }\end{array}$ & 1 & 2 & 3 & 4 & 5 \\
\hline $\begin{array}{l}\text { 8. We always see new faces replacing } \\
\text { old ones in our association. }\end{array}$ & 1 & 2 & 3 & 4 & 5 \\
\hline $\begin{array}{l}\text { 9. Our group doesn't mind selling tee-shirts, } \\
\text { logos and other paraphernalia with } \\
\text { the group name on them. }\end{array}$ & 1 & 2 & 3 & 4 & 5 \\
\hline $\begin{array}{l}\text { 10. Our members are not at all willing to } \\
\text { tell others about being a part of } \\
\text { this association. }\end{array}$ & 1 & 2 & 3 & 4 & 5 \\
\hline $\begin{array}{l}\text { 11. Most members stay with us for a } \\
\text { long time. }\end{array}$ & 1 & 2 & 3 & 4 & 5 \\
\hline $\begin{array}{l}\text { 12. Our association spends a significant } \\
\text { amount of time and effort in } \\
\text { promoting itself. }\end{array}$ & 1 & 2 & 3 & 4 & 5 \\
\hline
\end{tabular}




\section{Section III:}

Now, we would like to ask you your opinions about why your members belong to your association. How important are the following factors:

\begin{tabular}{|c|c|c|c|c|c|c|}
\hline & & $\begin{array}{l}\text { Not at } \\
\text { all }\end{array}$ & Somewhat & Moderately & Very & Extremely \\
\hline 1. & $\begin{array}{l}\text { The opinions of the management of } \\
\text { the association matter highly to } \\
\text { the members. }\end{array}$ & 1 & 2 & 3 & 4 & 5 \\
\hline 2. & $\begin{array}{l}\text { The endorsement of any program by } \\
\text { the association is critical in the decision } \\
\text { of the members to use it. }\end{array}$ & 1 & 2 & 3 & 4 & 5 \\
\hline 3. & $\begin{array}{l}\text { The leadership of the association is } \\
\text { trusted and valued by its members. }\end{array}$ & 1 & 2 & 3 & 4 & 5 \\
\hline 4. & $\begin{array}{l}\text { The members are able to help their } \\
\text { organisation without costing them any } \\
\text { additional money. }\end{array}$ & 1 & 2 & 3 & 4 & 5 \\
\hline 5. & $\begin{array}{l}\text { Membership allows both the member } \\
\text { and his/her organisation to be in a } \\
\text { 'win-win' situation. }\end{array}$ & 1 & 2 & 3 & 4 & 5 \\
\hline 6. & $\begin{array}{l}\text { The members consider the nature and } \\
\text { the mission of the group to be very } \\
\text { important. }\end{array}$ & 1 & 2 & 3 & 4 & 5 \\
\hline 7. & $\begin{array}{l}\text { Our members are very proud to be } \\
\text { affiliated to this group. }\end{array}$ & 1 & 2 & 3 & 4 & 5 \\
\hline 8. & $\begin{array}{l}\text { Members get discounts in hotels, } \\
\text { restaurants, rental agencies and at } \\
\text { other places because of their } \\
\text { memberships. }\end{array}$ & 1 & 2 & 3 & 4 & 5 \\
\hline 9. & $\begin{array}{l}\text { Members are able to easily access } \\
\text { the goods and services of the } \\
\text { association because of their } \\
\text { memberships. }\end{array}$ & 1 & 2 & 3 & 4 & 5 \\
\hline 10. & $\begin{array}{l}\text { Our members try to participate in } \\
\text { activities to show their support for } \\
\text { the association. }\end{array}$ & 1 & 2 & 3 & 4 & 5 \\
\hline 11. & $\begin{array}{l}\text { The membership enables the } \\
\text { members to support specific causes } \\
\text { that their organisation endorses. }\end{array}$ & 1 & 2 & 3 & 4 & 5 \\
\hline 12. & $\begin{array}{l}\text { Our members are personally likely to } \\
\text { know other people who belong to } \\
\text { this association. }\end{array}$ & 1 & 2 & 3 & 4 & 5 \\
\hline 13. & $\begin{array}{l}\text { The primary goal behind membership } \\
\text { is to enjoy the perks that come with it. }\end{array}$ & 1 & 2 & 3 & 4 & 5 \\
\hline 14. & $\begin{array}{l}\text { There are many additional benefits to } \\
\text { joining this association. }\end{array}$ & 1 & 2 & 3 & 4 & 5 \\
\hline
\end{tabular}

\section{Section IV:}

In this section, we are interested in your assessment of the general characteristics of your association. Please indicate how strongly you agree or disagree with each of the following statements:

\begin{tabular}{|c|c|c|c|c|c|}
\hline & $\begin{array}{l}\text { Strongly } \\
\text { disagree }\end{array}$ & Disagree & Neutral & Agree & $\begin{array}{l}\text { Strongly } \\
\text { agree }\end{array}$ \\
\hline 1. Ours is a very formal association. & 1 & 2 & 3 & 4 & 5 \\
\hline $\begin{array}{l}\text { 2. Our association is very selective about } \\
\text { admitting new members. }\end{array}$ & 1 & 2 & 3 & 4 & 5 \\
\hline $\begin{array}{l}\text { 3. There are several layers of management } \\
\text { in this association. }\end{array}$ & 1 & 2 & 3 & 4 & 5 \\
\hline $\begin{array}{l}\text { 4. Members who make their own decisions } \\
\text { would be quickly discouraged here. }\end{array}$ & 1 & 2 & 3 & 4 & 5 \\
\hline
\end{tabular}




\begin{tabular}{|c|c|c|c|c|c|}
\hline & $\begin{array}{l}\text { Strongly } \\
\text { disagree }\end{array}$ & Disagree & Neutral & Agree & $\begin{array}{l}\text { Strongly } \\
\text { agree }\end{array}$ \\
\hline $\begin{array}{l}\text { 5. It is very easy for someone to become a } \\
\text { member of our association. }\end{array}$ & 1 & 2 & 3 & 4 & 5 \\
\hline 6. Most members have similar backgrounds. & 1 & 2 & 3 & 4 & 5 \\
\hline $\begin{array}{l}\text { 7. Most of the members are involved in } \\
\text { other activities outside of the association. }\end{array}$ & 1 & 2 & 3 & 4 & 5 \\
\hline $\begin{array}{l}\text { 8. Members are allowed to do almost as } \\
\text { they please. }\end{array}$ & 1 & 2 & 3 & 4 & 5 \\
\hline $\begin{array}{l}\text { 9. There can be little action taken here } \\
\text { until the leadership approves a decision. }\end{array}$ & 1 & 2 & 3 & 4 & 5 \\
\hline $\begin{array}{l}\text { 10. Our association caters exclusively to } \\
\text { members that meet strict guidelines. }\end{array}$ & 1 & 2 & 3 & 4 & 5 \\
\hline $\begin{array}{l}\text { 11. Our association is only concerned with } \\
\text { local issues. }\end{array}$ & 1 & 2 & 3 & 4 & 5 \\
\hline $\begin{array}{l}\text { 12. Most of the members our association } \\
\text { live in the same region. }\end{array}$ & 1 & 2 & 3 & 4 & 5 \\
\hline $\begin{array}{l}\text { 13. A majority of the members have the same } \\
\text { demographic characteristics. }\end{array}$ & 1 & 2 & 3 & 4 & 5 \\
\hline $\begin{array}{l}\text { 14. Our association has branches in many } \\
\text { places. }\end{array}$ & 1 & 2 & 3 & 4 & 5 \\
\hline
\end{tabular}

\section{Section V:}

How likely are the following statements with respect to your association:

\begin{tabular}{|c|c|c|c|c|c|c|}
\hline & & $\begin{array}{l}\text { Very } \\
\text { unlikely }\end{array}$ & $\begin{array}{l}\text { Somewhat } \\
\text { unlikely }\end{array}$ & Neutral & $\begin{array}{l}\text { Somewhat } \\
\text { likely }\end{array}$ & $\begin{array}{l}\text { Very } \\
\text { likely }\end{array}$ \\
\hline 1. & $\begin{array}{l}\text { Our members will seriously consider products } \\
\text { and services recommended by the } \\
\text { association. }\end{array}$ & 1 & 2 & 3 & 4 & 5 \\
\hline & $\begin{array}{l}\text { Our members expect the association to sell } \\
\text { their names to other organisations. }\end{array}$ & 1 & 2 & 3 & 4 & 5 \\
\hline 3. & $\begin{array}{l}\text { Our members strictly conform to the } \\
\text { rules and regulations of the association. }\end{array}$ & 1 & 2 & 3 & 4 & 5 \\
\hline & $\begin{array}{l}\text { Our members rarely complain about } \\
\text { anything to the association. }\end{array}$ & 1 & 2 & 3 & 4 & 5 \\
\hline & $\begin{array}{l}\text { Our members talk to other people they } \\
\text { know, about the association. }\end{array}$ & 1 & 2 & 3 & 4 & 5 \\
\hline & $\begin{array}{l}\text { Most of the members of our association } \\
\text { are very entrepreneurial. }\end{array}$ & 1 & 2 & 3 & 4 & 5 \\
\hline 7. & $\begin{array}{l}\text { Our members are continually seeking } \\
\text { newer ways to improve the association. }\end{array}$ & 1 & 2 & 3 & 4 & 5 \\
\hline 8. & $\begin{array}{l}\text { The members are very modern in their } \\
\text { outlook to life. }\end{array}$ & 1 & 2 & 3 & 4 & 5 \\
\hline 9. & $\begin{array}{l}\text { Our members 'keep up' with developments } \\
\text { in the association. }\end{array}$ & 1 & 2 & 3 & 4 & 5 \\
\hline & $\begin{array}{l}\text { The members are likely to willingly give } \\
\text { their time to help the association. }\end{array}$ & 1 & 2 & 3 & 4 & 5 \\
\hline & $\begin{array}{l}\text { They like receiving benefits from other } \\
\text { organisations as a result of their } \\
\text { membership in this association. }\end{array}$ & 1 & 2 & 3 & 4 & 5 \\
\hline & $\begin{array}{l}\text { Our members conscientiously follow the } \\
\text { rules and regulations of the association. }\end{array}$ & 1 & 2 & 3 & 4 & 5 \\
\hline 13. & $\begin{array}{l}\text { Our members strictly adhere to the policies } \\
\text { of the association. }\end{array}$ & 1 & 2 & 3 & 4 & 5 \\
\hline
\end{tabular}




\section{Section VI:}

How strongly do you agree or disagree with the following adjectives or phrases that identify qualities that the leadership in your association may have, actions they may take, or their personal feelings toward the members of the association:

\begin{tabular}{|c|c|c|c|c|c|c|}
\hline & & $\begin{array}{l}\text { Strongly } \\
\text { disagree }\end{array}$ & Disagree & Neutral & Agree & $\begin{array}{l}\text { Strongly } \\
\text { agree }\end{array}$ \\
\hline 1. & $\begin{array}{l}\text { The members couldn't care less what the } \\
\text { association thinks of them. }\end{array}$ & 1 & 2 & 3 & 4 & 5 \\
\hline 2. & $\begin{array}{l}\text { The association has the expertise to } \\
\text { make the right decisions. }\end{array}$ & 1 & 2 & 3 & 4 & 5 \\
\hline 3. & $\begin{array}{l}\text { The members admire the association } \\
\text { and want to act in a way to merit } \\
\text { its respect. }\end{array}$ & 1 & 2 & 3 & 4 & 5 \\
\hline 4. & $\begin{array}{l}\text { The association leadership is competent } \\
\text { to make an assessment of the } \\
\text { various options. }\end{array}$ & 1 & 2 & 3 & 4 & 5 \\
\hline 5. & $\begin{array}{l}\text { This association has a right to expect } \\
\text { its members to follow instructions. }\end{array}$ & 1 & 2 & 3 & 4 & 5 \\
\hline 6. & $\begin{array}{l}\text { The association is entitled to direct the } \\
\text { actions of its members. }\end{array}$ & 1 & 2 & 3 & 4 & 5 \\
\hline 7. & $\begin{array}{l}\text { The approval of the association's } \\
\text { leadership means a lot to the members. }\end{array}$ & 1 & 2 & 3 & 4 & 5 \\
\hline 8. & $\begin{array}{l}\text { The association has the right to } \\
\text { expect the members' cooperation. }\end{array}$ & 1 & 2 & 3 & 4 & 5 \\
\hline 9. & $\begin{array}{l}\text { The association is knowledgeable } \\
\text { about members' needs. }\end{array}$ & 1 & 2 & 3 & 4 & 5 \\
\hline
\end{tabular}

\section{Section VII:}

These questions relate to what your association is like. Each of these items contains four descriptions of associations. Please distribute 100 points among the four descriptions depending on how well they apply to your organization. None of the descriptions are any better than any other; they are just different. For each question, please use all 100 points. You may divide the points in any way you wish. Most associations will be a mixture of the descriptions provided.

1. Kind of Association (Please distribute 100 points among the following four choices)

Our association is a very personal place. It is like an extended family. People tend to share a lot of themselves.

Our association is a very dynamic and entrepreneurial place. People are willing to stick their necks out and take risks.

Our association is a very formalised and structured place. Established procedures generally govern what people do.

Our association is a very business oriented. A major concern is with getting the job done, without much personal involvement.

2. Leadership (Please distribute $\mathbf{1 0 0}$ points among the following four choices) The head of our association is considered to be a mentor, sage, or a parent figure.

The head of our association is generally considered to be an entrepreneur, innovator, or risk taker. 
The head of our association is generally considered to be a coordinator, an organiser, or an administrator.

The head of our association is usually considered to be a producer or a hard driver.

3. What holds the Association Together (Please distribute 100 points among the following four choices)

The glue that holds our association together is loyalty and tradition.

The glue that holds our association together is a commitment to

innovation and development.

The glue that holds our association together is formal rules and policies.

The glue that holds our association together is the emphasis of tasks and goal accomplishment.

4. What is Important (Please distribute $\mathbf{1 0 0}$ points among the following four choices)

Our association emphasises stability and permanence. Efficient smooth operations are important.

Our association emphasises competitive actions and achievement. Measurable goals are important.

Our association emphasises human resources. High cohesion and morale are important.

Our association emphasises growth and acquiring new resources.

Readiness to meet new challenges are important.

\section{Section VIII:}

Finally, please tell us a few facts about you that we need strictly for statistical purposes:

1. Are you:

Male Female?

2. How long have you been a member of this association?

3. How many other associations are you a member?

4a. Do you hold any official position within this association? - Yes No

$4 \mathrm{~b}$. If yes, what is the title of your position:

4c. Is this: a paid position, or a voluntary position?

5. Does your association try to influence legislation at the state or federal level? Yes No

Thank you once again, for your time and consideration. Your assistance in our research is very much appreciated. Please mail this completed survey using the stamped envelope provided. Thanks, again! 